\title{
TRAILS TO IMPROVE GROWTH AND CARCASS QUALITY IN DUCK
}

\author{
Hegazi, S M., Gaffar, K. ${ }^{(1)}$ and Sakr, O., ${ }^{(2)}$ \\ Nutrition and Clinical Nutrition DPT, Faculty of Veterinary \\ Medicine Kafrelsheikh University \\ (1) Nutrition and Clinical Nutrition DPT, Faculty of Veterinary \\ Medicine El-Sadaat city, El-Mnofia University \\ (2) Regional Animal Health Research Institute, Kafrelsheikh
}

\begin{abstract}
Reducing fat in duck lean is consider the first step towards improving carcass quality. A total of 144 male and female, one day old white Peking ducks were divided into 6 equal groups, each group subdivided into 2 subgroup. One of them contain 12 males while the other contain 12 females.
\end{abstract}

Six dietary treatments were applied for both males and females have the same group number. Basal diet supplemented with salbutamole $2 \mathrm{mg}$ for 56 days (whole experiment period)(Treatment 1), or from 29-56 days of age)(Treatment 2), basal diet supplemented with Chromium Piclonate $2 \mathrm{mg})($ Treatment 3), modified calorie protein ratio diet by increasing protein concentration $0.5 \%$ (0-2 weeks) and $2 \%$ (3-8 weeks) (Treatment 4), basal diet but after reduce the recommended level to $95 \%$ of control diet for starter period and to $90 \%$ of control diet for grower and finisher periods)(Treatment 5), while basal diet without supplementation, modification, or restriction was as control (Treatment 6). 
The results concerning growth performance demonstrated that salbutamol or chromium supplementation and decreased calorie protein ratio improved all parameters of growth performance. While restricted diet reduced final body weight and final body weight gain but feed conversion ratio was improved.

Carcass traits showed that dressing percentage and breast muscle was increased. Skin and sub-cuteness Fat percentage was decreased. Meanwhile, abdominal fat was reduced significantly with all dietary treatments as compared with control. Also, chemical analysis of meat demonstrated that muscular fat was decreased significantly in all treatments compared with control, however, moisture content was increased.

Serum analysis showed that total cholesterol was decreased with all dietary treatments while serum protein increased insignificantly in all female groups but was significantly increased in all male groups as compared with control.

It could be concluded that salbutamole and chromium supplementation or decreased calori protein ratio improved all growth performance, but restricted diet reduced final body weight while feed conversion ratio improved. Dressing percentage and carcass characteristics were improved with all dietary treatments. And cholesterol and cholesterol L.D.L. reduced with all experimental treatments in both sexes compared with control ..

Key wards: Duck,Carcass quality, Salbutamole, Chromium, Calorie protein ratio, Feed restriction, Fat, Cholesterol. 


\section{INTRODUCTION}

Ducks are one of the poultry species kept mainly for meat production. Although their fine meat quality, some people unlike meat of duck because of it's high content of fat. Different previous investigations were interested in improving carcass quality and growth performance of broilers using feed additives, Murdoch et al., (2006) reported that beta-adrenergic agonists repartition nutrients from fat to muscle protein which increases feed efficiency. Kim et al. (1995) concluded that carcass fat was decreased and carcass protein was increased with added chromium picolinate (200 $\mathrm{ppb}$ ) to the broilers diet. Moreover, Amatya et al. (2004) reported that Metabolizability of the organic nutrients in broiler chicks were increased in the $\mathrm{Cr}$ supplemented groups.

Modification of calorie protein ratio also was reported to affect body fat by increasing Lipogenic activity as this ratio was increased (Donaldson, 1985).

Feed restriction on the other hand, was reported to affect carcass analysis of the broilers where it accompanied by a decreasing proportion of fat (Bennett and Leeson, 1990).

The current study objectives was to improve carcass quality and growth performance of white Peking ducks using beta adrenergic agonist and chromium as a feed additives supplement, modified calorie/protein ratio and restricted feed recommendation. 


\section{MATERIALS AND METHODS}

\subsection{Experimental Birds:}

A total of 144 one day old white Peking ducks were used in this experiment. The ducklings were obtained from the General Egypt Poultry Organization. They were divided into 6 equal groups : Each group was subdivided into 2 subgroup. One of them contain 12 males while the other contain 12 females. Males and females of each treatment have the same group number but housed separately in compartment which was bedded by fresh clean wood shave forming a deep litter of $4 \mathrm{~cm}$ depth and changed every two days. Each compartment was provided with continuous lightening program, suitable feeder and waterer. Prophylactic antibiotics program measures against the most common infectious bacterial and viral diseases were carried out.

\subsection{Experimental feeding program:}

The present feeding trial was lasted 8 weeks. the basal diet of two phases experiment were formulated according to N.R.C. recommendations for ducks (1994) from yellow corn, soybean, corn gluten and wheat bran after chemical analysis of these feedstuff $(A O A C, 1984)$.

Table (1): Chemical analysis of feed stuffs used in experimental diet.

\begin{tabular}{|c|c|c|c|c|}
\hline Nutrients $(\%)$ & Yellow corn & $\begin{array}{c}\text { Soybean meal } \\
44 \% \mathrm{CP}\end{array}$ & $\begin{array}{c}\text { Corn gluten } \\
62 \% \mathrm{CP}\end{array}$ & Wheat bran \\
\hline$\overline{\text { Moisture }}$ & 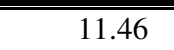 & 9.96 & $\overline{7.27}$ & 9.53 \\
\hline Dry Matter & 88.54 & 90.34 & 92.73 & 90.47 \\
\hline Crude Protein & 7.76 & 42.48 & 61.34 & 14.88 \\
\hline $\mathrm{ADF}$ & 2.00 & 8.00 & 6.00 & 10 \\
\hline Crude Fat & 3.50 & 2.00 & 1.67 & 2.33 \\
\hline
\end{tabular}

Kafrelsheikh Vet. Med. J. Vol. 7 No. 1 (2009) 
Trails To Improve Growth And Carcass Quality In Duck.

Table (2): Physical and chemical composition of the experimental diets.

\begin{tabular}{|c|c|c|c|c|}
\hline \multirow{2}{*}{ Physical composition } & \multicolumn{2}{|c|}{ Basal Diet } & \multicolumn{2}{|c|}{ Modified Diet } \\
\hline & Starter & $\begin{array}{c}\text { Grower and } \\
\text { finisher }\end{array}$ & Starter & $\begin{array}{c}\text { Grower and } \\
\text { finisher }\end{array}$ \\
\hline Yellow corn & 58.345 & 69.305 & 57.274 & 66.43 \\
\hline Soybean meal $44 \%$ & 33.2 & 23.5 & 33.7 & 30 \\
\hline Corn gluten $62 \%$ & 5.5 & - & 6.1 & - \\
\hline Wheat bran & - & 4.7 & - & 1.15 \\
\hline Dicalcium phosphate & 1.45 & 1.25 & 1.42 & 1.2 \\
\hline Lime stone & 0.33 & 0.37 & 0.37 & 0.37 \\
\hline Lysine & 0.1 & - & 0.08 & - \\
\hline Methionine & 0.025 & 0.025 & 0.006 & - \\
\hline Choline $50 \%$ & 0.4 & 0.2 & 0.4 & 0.2 \\
\hline Common salt & 0.4 & 0.4 & 0.4 & 0.4 \\
\hline Premix ${ }^{1^{*}}$ & 0.25 & 0.25 & 0.25 & 0.25 \\
\hline \multicolumn{5}{|l|}{ Chemical composition\% } \\
\hline Moisture & 10.39 & 10.62 & 10.36 & 10.71 \\
\hline $\mathrm{ME} \mathrm{Kcal} / \mathrm{kg} *$ & 2899.5 & 2906.8 & 2897.1 & 2909.3 \\
\hline Crude protein & 22.00 & 16.059 & 22.5 & 18.069 \\
\hline Calorie / protein ratio & 131.77 & 181 & 128.76 & 161 \\
\hline Ether extract & 2.77 & 3 & 2.77 & 2.95 \\
\hline Calcium & 0.65 & 0.6 & 0.65 & 0.6 \\
\hline Available phosphorus & 0.404 & 0.35 & 0.4 & 0.35 \\
\hline Lysine & 1.2 & 0.84 & 1.2 & 0.98 \\
\hline Methionine + cystine & 0.8 & 0.6 & 0.8 & 0.62 \\
\hline Choline (mg/kg diet) & 2000 & 1000 & 2000 & 1000 \\
\hline
\end{tabular}

* ME was calculated according to NRC tables (1994).

** The used premix (Teiba Agri. Vet. Co.) composed of vitamin A 10000000 IU, vitamin $\mathrm{D}_{3}$ $2500000 \mathrm{IU}$, vitamin E $20000 \mathrm{mg}$, vitamin $\mathrm{K}_{3} 1500 \mathrm{mg}$, vitamin $\mathrm{B}_{1} 1000 \mathrm{mg}$, vitamin $\mathrm{B}_{2}$ $5000 \mathrm{mg}$, vitamin $B_{6} 1500 \mathrm{mg}$, vitamin $B_{12} 15 \mathrm{mg}$, Pantothenic acid $15000 \mathrm{mg}$, Nicotinic acid $30000 \mathrm{mg}$, Folic acid $1000 \mathrm{mg}$, Biotin $50 \mathrm{mg}$, Iron $40000 \mathrm{mg}$, Manganese $80000 \mathrm{mg}$, Copper $10000 \mathrm{mg}$, Zinc $60000 \mathrm{mg}$, Iodine $1000 \mathrm{mg}$, Cobalt $500 \mathrm{mg}$, Selenium $150 \mathrm{mg}$, Anti-oxidant $5000 \mathrm{mg}$ and calcium carbonate $\left(\mathrm{CaCO}_{3}\right)$ carrier to $2500 \mathrm{~g}$.

Kafrelsheikh Vet. Med. J. Vol. 7 No. 1 (2009) 
The design during the experimental period is carried out using 6 dietary treatments as follow: Duckling of group 1 were fed on basal diet supplemented with Salbutamole 2mg/kg (GlaxoWellcome Pharmaceutical company) for whole growing period. Ducklings of group 2 were fed on basal diet supplemented with Salbutamole $2 \mathrm{mg} / \mathrm{kg}$ for the last 4 weeks of the experiment (from 29 - 56 days of age). Ducklings of group 3 were fed on basal diet supplemented with Chromium Piclonate $2 \mathrm{mg} / \mathrm{kg}$ (Amoun Pharmaceutical company). Ducklings of group 4 were fed on modified calorie protein ratio diet by increasing protein concentration $0.5 \%$ in starter diet (0-2 weeks) and $2 \%$ in growing, finishing diet (3-8 weeks). Ducklings of group 5 were fed on basal diet but after reduction the recommended level at rate 5\% for starter period and $10 \%$ for grower and finisher periods. Duckling of group 6 represented the control group and fed on basal diet without feed additive, modification or restriction. This design was used in both sexes at the same arrangement for each treatment.

\subsection{Experiment Parameters:}

2.3.1. Effect of the using experimental diets on weekly and cumulative growth, feed intake and feed conversion ratio were measured.

2.3.2. Chemical analysis of muscles for crud protein, crud fat and moisture were determined at the end of the experiment (AOAC, 1984).

2.3.3. Abdominal fat, skin plus subcutaneous fat, breast muscle, leg muscle, proventruclus, gastro intestinal tract, spleen and pancreas weight and their relative weights to body weight were recorded.

2.3.4. Serum total protein (Doumas et al., 1981), cholesterol (Schettler et al., 1975), triglycerides (Fossatip, 1982). Serum HDL (High density lipoprotein) and LDL (Low density lipoprotein) (Young, 1995) were demonstrated. 


\subsection{Statistical analysis:}

The analysis of variance for the obtained data was performed using statistical analysis system: (SAS, 1987) to assess significant differences.

\section{Results and Discussion:}

\section{1- Growth Performance:}

The growth performance data are summarized in tables $(3,4)$ for both male and female respectively.

Regarding the effect of first two dietary treatments "salbutamol" as feed additive $2 \mathrm{mg} / \mathrm{kg}$ diet for whole growing period or for the last half of experimental period, the achieved data showed the superiority of these treatments, and this improvement was significantly in FCR. and final body gain in female group supplemented with salbutamol for whole growing period compared with control. These results are in agreement with that obtained by Hegazi et al., (2001) who reported that growth weight, and feed conversion ratio demonstrate significant response due to feed additive salbutamol, and confirmed by Fawcett et al., (2004) who reported that salbutamol lowered feed intake, and improved feed conversion ratio in both sexes.

Concerning the effect of feed additive chromium $2 \mathrm{mg} / \mathrm{kg}$ diet. Our results are similar to those obtained by $\mathbf{L u}$ MinZhi et al., (2002) who studied the effect of chromium 0.2 and $0.4 \mathrm{mg} \mathrm{Cr} / \mathrm{kg}$ diet on growth performance of ducks meat, and stated that $\mathrm{Cr}$ promoted growth rate, but insignificant difference in FCR was recorded. 
The data interested in the effect of feeding decreased calorie / protein ratio as compared with that of basal diet. The obtained results are in accordance with that obtained by Salmon (1986) who reported that increasing Energy to protein ratio resulted in linear decreases in feed intake, and efficiency of feed utilization. Also, these results were confirmed by Silva et al., (2001) who found that increasing the ME : CP ratio result in linear decrease in live weight.

The effect of 5 to $10 \%$ feed restriction for starting, and growing, finishing phases respectively on growth, demonstrated higher feed conversion as compared to the control for both male and female. Our results are in agreement with that obtained by Parrilla (1984). Klemm and Pingel (1985) fed ducks on ad lib feeding or reduced to $90 \%$ of ad lib, and found that males and females on the restricted diet had higher FCR. The results confirmed by Mansour et al., (2004) who concluded that 90 $\%$ feed restriction level provided a benefit on FCR.

\section{2- Carcass Traits:}

Carcass characteristics data are presented in tables $(5,6)$ for both male and female respectively while the effect of the used dietary treatments on muscular chemical composition in male and female ducks are shown in tables $(7,8)$ respectively.

The analysis of variance of the present data showed that duck groups fed diet supplemented with beta - agonist salbutamol $2 \mathrm{mg} / \mathrm{kg}$ diet for the whole growing period or for 28 days (from 29 - 56 days) were significantly increased dressing percentage and showed significant decrease of abdominal fat in both male and female groups as compared with control. The results are confirmed by Gonzalez et al., (2000), Hegazi et al., (2001) and Fawcett et al., (2004) who found that the relative weight of the fat pad was significantly decreased in birds of both sexes given diets containing salbutamol. 
Regarding the results of the chromium dietary supplementation on abdominal fat and dressing percentage, it is noticed that there were significant decrease in abdominal fat and significant increase in dressing percentage as compared with control in both male and female. The results are similar to those obtained by $\mathbf{L} \boldsymbol{M}$ MinZhi et al., (2002) who studied the effect of chromium ( 0.2 and $0.4 \mathrm{mg} \mathrm{Cr} / \mathrm{kg}$ diet) on carcass characteristics of ducks meat ( $1-49$ days). They stated that chromium reduced abdominal fat by $(16-26 \%)$ and subcutaneous fat by $(9-10 \%)$ significantly and improved carcass quality.

The effect of decreased calorie protein ratio dietary treatment showed significant increase in carcass yield in case of female, although the difference was not significant. The abdominal fat was significantly decreased in both sexes as compared with control. The results are similar to those obtained by Silva et al., (2001) who reported that increasing the calorie protein ratio resulted in a linear decrease in carcass weight. The results are also similar to those obtained by Hermawan (1997) and Tion et.al., (2005) who found that fat weight and fat percentage were significantly $(\mathrm{P}<0.05)$ affected by the calorie protein ratio.

The results concerning groups fed on $(5-10 \%)$ restricted amount of diet showed significantly carcass yield increase in case of male ducks as compared with control but the increase was not significant in female groups as compared with female control group, while abdominal fat decreased significantly in both sexes. The results are in agreement with that obtained by Teimouri et al., (2005). Moreover, Mansour et al., (2004) reported that broilers received $90,80,70 \%$ of the average full fed diet of control showed in slaughtering age at 42 days significant increase in the yields of dressing. The results are similar to those obtained by Li. YuXin et al., (2003) and Shariatmadari and Sahraie (2003) who found that abdominal fat was significantly $(\mathrm{P}<0.05)$ reduced by decreasing feed intake or diluting the finisher diet. 
The data of muscular chemical composition in male and female ducks, tables $(7,8)$ respectively, showed significant higher muscular moisture content in all male and female groups, with the exception male group supplemented with salbutamol $2 \mathrm{mg}$ for whole growing period which showed non-significant higher moisture. The results showed also nonsignificant higher protein content in all experimental groups. In the same time, the present data showed significant reduced muscular fat content with all treatments. This was in accordance with the results obtained by Hegazi et. al., (2001) who found that administering salbutamol reduced muscular fat significantly $(\mathrm{P}<0.05)$. The results are also similar to those obtained by Schiavone et. al., (2004) who reported that slight improvement of protein content was observed in beta-agonist clenbutarol treated groups and confirmed by Murdoch et. al., (2006) who reported that beta adrenergic agonists repartitioned nutrients from fat to muscle protein.

The results concerning duck groups fed on diet supplemented with chromium are similar to those obtained by Choct et. al., (2005) who found that chromium reduced breast meat fat content and increased carcass water content significantly $(\mathrm{P}<0.05)$. The results are also similar to those obtained by Kim et. al., (1996) and Amatya et. al., (2004) who stated that protein accretion in the meat tended to be increased in the chromium supplemented groups.

In the same aspect, the data concerning duck groups fed on decreased calorie protein ratio are similar to those obtained by Shrivastav and Panda (1982) who reported that male birds had higher percentage of moisture and lower percentage of protein and fat in thigh and breast meat than had females in there were changes in both sexes for protein and fat content with increasing dietary energy protein ratio. These results are similar to those obtained by Bennett and Leeson (1990) who reported that carcass analysis of feed restricted broilers breeder pullets accompanied by a decreasing proportion of fat and relatively constant protein content $(20-21 \%)$. 


\section{4- Serum traits:}

Data concerned with the influence of dietary treatments on some serum traits in both male and female are presented in tables $(9,10)$ respectively.

Duck groups fed on diet supplemented with salbutamol $2 \mathrm{mg} / \mathrm{kg}$ diet are in harmony with those obtained by Hegazi et. al., (2001) who fed 1-day old chicks on diets supplemented with salbutamol $2 \mathrm{mg} / \mathrm{kg}$ diet for different feeding periods (day 1 -49, 22 -49 and 35-49) and found that serum cholesterol significant reduced. However, serum total protein showed significant increase in the last phase of the experiment.

Regarding the group fed on diet supplemented with chromium, the results are in agreement to those obtained by Kroliezewska et. al., (2004) who found that supplementation with chromium decreased serum total cholesterol significantly $(\mathrm{P}<0.05)$ and increased serum total protein and caused increase in HDL cholesterol.

The data interested in the duck group fed on decreased calorie protein ratio are similar to those obtained by Ugwuene and Omueti (2000).

The results concerning with groups fed on restricted diet are similar in female groups with that obtained by Demir et. al., (2004) who reported that total cholesterol significantly $(\mathrm{P}<0.05)$ affected by feeding regimes in broilers while the results in male groups are similar to those obtained by Santoso (2001) who reported that cholesterol concentration was not significantly differed by feeding regimes, the results are also in agreement with that obtained by Fariborz and Dordi (2005) who found that feed restriction resulted in enhanced the activity of serum HDL. 
It could be concluded that salbutamole and chromium supplementation or decreased calori protein ratio improved all growth performance. While restricted diet reduce final body weight and final but feed conversion ratio improved.

Dressing percentage, carcass lean, skin plus subcutaneous fat, muscular fat and abdominal fat were improved with all dietary treatments.

Total cholesterol and cholesterol L.D.L. reduced with all experimental treatments in both sexes compared with control. Moreover, muscular moisture and total serum protein were improved with all dietary treatments.

\section{REFERENCES}

- Amatya., J.L.; Haldar., S. and Ghosh., T.K. (2004): Effects of chromium supplementation from inorganic and organic sources on nutrient utilization, mineral metabolism and meat quality in broiler chickens exposed to natural heat stress. Animal. Science. 79(2): 241-253.

- Association of official Analytical chemists (1984): Official methods of analysis $13^{\text {th }}$ ed. Washington D.C., USA.

- Bennett., C.D. and Leeson., S. (1990): Body composition of the broilerbreeder pullet . Poultry-Science. 69(5): 715-720.

- Choct.,M.;Naylor.,A.J.and Oddy., V.H. (2005): Dietary manipulation of lean tissue deposition in broiler chickens. Asian - Australasian Journal - of - Animal - Sciences. 18(5): 692-698.

- Demir., E.; Sarica., S.; Sekeroglu., A.; Ozcan., M.A. and Seker., Y. (2004): Effects of early and late feed restriction or feed withdrawal on growth performance, ascites and blood constituents of broiler chickens. Acta- Agriculturae- Scandinavica -Section-A,- Animal - Science. 54 (3): 152-158. 
- Domuas, B.T.; Bayso,D.D.; Carter.R..;Peters, T and Schaffer. (1981): Determinations of total serum protein. Clin. Chem., 27: 1642-1643.

- Donaldson., W.E. (1985): Lipogenesis and body fat in chicks: effects of calorie-protein ratio and dietary fat. Poultry-Science. 64(6): 11991204.

- Fariborz. Khajali. and Dordi. Qujeq. (2005): Relationship between growth and serum lactate dehydrogenase activity and the development of ascites in broilers subjected to skip-a-day feed restriction. International-Journal-of-Poultry-Science. 4(5): 317-319 .

- Fawcett., J.P.; Ravindran., V.; Morel., P.C.H.; Zhang., M.; Ciofalo., V.B.; Spainhour., C.B. and Aberg., G. (2004): Influence of salbutamol administered as the single active enantiomer (R-salbutamol) on the growth performance and carcass characteristics of broiler chickens Animal-Science. 78(1): 23-30 .

- Fossatip, P. (1982): Clin. Chem. 28 : 2077 (Cited in pamphlet of BioMeriéux Kits).

- Gonzalez. Alvarado., J.M.; Suarez. Oporta., M.E.; Pro. Martinez., A. and Lopez. Coello., C. (2000): Feed restriction and salbutamol to control ascites syndrome in broilers: 1. Productive performance and carcass traits . Agrociencia. 34(3): 283-292.

- Hegazy, S.M., Magda, Sh. Taha, and Abo-Elmagd, M.K (2001): Influence of supplemental salbutamol and chromium on growth performance and carcass quality of broilers . the $2^{\text {nd }}$ International Scientific Conference, 781-794, Mansoura, Egypt, 8-9 April, 2001.

- Hermawan., D. (1997): Effect of dietary energy to protein ratio and chlorpropamide intake on broilers . Publikasi - Berkala - Penelitian Pascasarjana - Universitas - Padjadjaran. 8 (1): 98-107. 
- Kim., S.W.;Han., I.K.; Choi., Y.J.; Kim., Y.H.; Shin., I.S. and Chae., B.J. (1995): Effects of chromium picolinate on growth performance, carcass composition and serum traits of broilers fed dietary different levels of crude protein . Asian-Australasian-Journal-of-Animal-Sciences. 8(5): 463-470.

- Kim., Y.H.; Han.,I.K.; Choi., Y.J.; Shin., I.S.; Chae., B.J. and Kang., T.H. (1996): Effects of dietary levels of chromium picolinate on growth performance, carcass quality and serum traits in broiler chicks . Asian-Australasian-Journal-of-Animal-Sciences. 9(3): 341-347 .

- Klemm., R. and Pingel., H. (1985): Effect of selection for low feed conversion with restricted feeding of growing ducks. $6^{\text {th }}$-InternationalSymposium-on-Actual-Problems-of-Avian-Genetics. 24-32 .

- Kroliczewska., B.; Zawadzki., W.; Dobrzanski., Z. and Kaczmarek. Oliwa., A. (2004): Changes in selected serum parameters of broiler chicken fed supplemental chromium Journal-of-Animal-Physiologyand-Animal-Nutrition. 88(11/12): 393-400 .

- Li. YuXin.; Guo. YuMing.; Cao. BingHai.; Yuan. JianMin. and Nie. Wei. (2003): Effect of different dietary energy and protein restriction during early growing period on the compensatory growth of broilers . Chinese-Journal-of-Animal-Science. 39(3): 5-7.

- Lu. MinZhi.; Ye. WeiXiong.; Huang. DeCun.; Yang. ChengZhong.; Su. WeiXue. and Cai. LaiChang. (2002): Experiment of chromium supplementation in basic diet of meat ducks. China-Poultry. 24 (4): 8.

- Mansour., K.M.; Siam., S.S. and Osman., A.M.R. (2004): Effects of age and quantitative feed restriction prior to slaughtering on the performance, carcass characteristics and some blood constituents of broilers . Egyptian-Poultry-Science-Journal. 24(2): 509-522 . 
- Murdoch., G-K; Okine - E-K; and Christopherson R-J., (2006): Metabolic modifiers in animal nutrition : potential benefits and risks. Biology of nutrition in growing animals; 135-178.

- NRC (1994): Nutrient requirements of poultry, ninth revised edition, National Academy Press, Washington DC.

- Parrilla., E.T. (1984): Performance of meat-type ducklings on different levels of feed restriction. Annals-of-Tropical-Research. 6: 42-52.

- Salmon., R.E. (1986): Effect of nutrient density and energy to protein ratio on performance and carcase quality of Small White turkeys . British-Poultry-Science. 27(4): 629-638 .

- Santoso., U. (2001): Effects of early feed restriction on growth, fat accumulation and meat composition in unsexed broiler chickens . Asian-Australasian-Journal-of-Animal-Sciences. 14(11): 1585-1591 .

- SAS (1987): Statistical analysis system user's guide statistics. As. Institute Cary, North Carolina.

- Schettler, G.; Nussel, E.; Arrbetsrred, S.and Praventive, M.E.D. (1975): Determination of cholesterol in blood Ann. Clin. Biochem. 1010-25.

- Schiavone.A.;Tarantola., M.;Perona., G.; Pagliasso., S.; Badino., P.; Odore., R.; Cuniberti., B. and Lussiana., C. (2004): Effect of dietary clenbuterol and cimaterol on muscle composition, beta -adrenergic and androgen receptor concentrations in broiler chickens. Journal-ofAnimal-Physiology-and-Animal-Nutrition. 88(4): 94-100 .

- Shariatmadari., F. and Sahraie., S.H. (2003): Effect of food restriction during the finishing period on the performance of broiler chickens. British-Poultry-Science. 44(1, Supplement): S40-S41. 
- Shrivastav., A.K. and Panda., B. (1982): Effect of increasing calorieprotein ratio during growing period (4-5 weeks) on dressing yield and chemical composition of quail meat .Indian-Journal-of-Poultry-Science. 17(4): 253-256 .

- Silva., J.H.V.da.; Albino., L.F.T. and Nascimento., A.H.do. (2001): Energy levels and metabolizable energy: protein ratio for male broiler chicks from 22 to 42 days of age. Revista-Brasileira-de-Zootecnia. 30(6): 1791-1800.

- Suksombat., W.; Kanchanatawee., S. (2005): Effects of various sources and levels of chromium on performance of broilers. Asian-AustralasianJournal-of-Animal-Sciences. 18(11): 1628-1633.

- Teimouri., A.; Rezaei,, M,; Pourreza., J.; Sayyahzadeh., H. and Waldroup., P.W. (2005): Effect of diet dilution in the starter period on performance and carcass characteristics of broiler chicks. InternationalJournal-of-Poultry-Science. 4(12): 1006-1011.

- Tion.,M.A.;Orga.,M.T. and Adeka., I.A. (2005): The effect of calorie to protein ratio of practical diets on performance and carcass quality of broiler chickens.Nigerian-Journal-of-Animal-Production.32(1/2):253-260

- Ugwuene,-M-C;Omueti,-J-O (2000):Comparison of fish and chicken intestine meals as animal protein sources in broiler diets. Journal-ofSustainable-Agriculture-and-the-Environment. 2(1): 20-25.

- Young DS. (1995): Effects of drugs on clinical laboratory tests $4^{\text {th }}$ ed. AACC Press. (Cited in pamphlet of BioSystems). 


\section{محاولات لزيادة كثاءة النمو وتحسين مواصفات الذبيحة في البط}

تمثل خفض نسبة الدهون و الكولسترول الخطوة الأولى باتجاه تحسين مواصفات اللحم • وقد نم اختيار البط لإجراء هذه الدراسة نظراً لاحتوائه علي نسبة عالية من الدهون . وقد بدأت هذه التجربة بعدد 144 بطة عمر يوم نصفهم من الذكور والنصف الآخر من الإناث تم توزيعهم بنسبة 24 بطة لكل مجموعة حيث تتكون كل مجموعة من مكررين إحداهما بها عدد 12 من الإناث و الأخرى بها عدد 12 من الذكور ، حيث تم مقارنة الذكور بالمجموعة الضابطة الخاصة بها وكذلك مقارنة الإناث بالمجموعة الضابطة الخاصة بها. وفي هذه الدراسة تم إضافة مادة السالبيوتامول بمعدل 2 مللي جر ام لكل كجم عليقه طو ال فترة النمو في المجموعة الأولى أو من عمر 29 - 56 يوم في المجموعة الثانية ، أما المجموعة الثالثة فقد تم إضافة الكروميوم بايكلونيت بمعدل 2 مللي جر ام لكل كجم عليقه ، وفي المجمو عة الر ابعة نم زيادة نسبة البروتين في العليقة بنسبة 0.5 \% من عمر 1 - 15 يوم بينما زادت بنسبة 2 \% من عمر 16 - 56 يوم ، حتى تقل نسبة الطاقة إلى البروتين عن العلائق الضابطة ، و المجموعة الخامسة فقد غذيت علي عليقه محددة بنسبة 95 \% من كميه العليقة الضابطة من عمر 1 - 15 يوم وبنسبة 90\% من كمية العليقة الضابطة من عمر 16 يوم حتى نهاية التجربة أما المجموعة السادسة فقد غذيت علي العليقة الضابطة بدون إضافات وبدون تغيير في مو اصفات العليقة و غير مخفضة من حيث الكميه.

وقد أظهرت نتائج البحث أن جميع المعاملات أدت إلي تحسن في كفاءة النمو ما عدا المجموعة الني غذيت علي عليقه مخفضه في الكمية حيث لوحظ انخفاض في منوسط الوزن ومتوسط الزيادة في الوزن ومعيار النمو إلا أن معامل التحويل الغذائي كان أفضل بالمقارنة

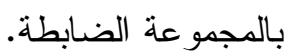


أما نتائج مو اصفات الذبيحة قد أظهرت تحسن ملحوظ في نسبة التصافي و الجلد و الدهن تحت الجلد ، إلا أن دهن البطن فلقد انخفض انخفاضاً معنوياً مع كل المعاملات بالمقارنة مع المجموعة الضابطة .

هذا وقد أظهرت نتائج التحليل الكيميائي زيادة ا للحم زيادة معنوية في نسبة الرطوبة إلا أن هذه الزيادة لم تكن معنوية في مجموعة الذكور التي غذيت علي عليقه مضاف إليها السالبيوتامول طو ال فترة النمو ، بينما انخفضت نسبة الدهن في اللحم انخفاضاً معنوياً في كل المجموعات بالمقارنة بالمجموعة الضابطة وزادت نسبة البروتين إلا أن هذه الزيادة لم تكن معنوية مع كل المعاملات بالمقارنة مع المجمو عة الضابطة .

أما نتائج قياس المصل فقد أظهرت أن نسبة الكولسترول الكلي قد انخفضت في كل المجموعات بالمقارنة بالمجموعة الضابطة في حين زادت نسبة البروتين في المصل زيادة غير معنوية في كل مجموعات الإناث، بينما كانت هذه الزيادة معنوية في كل مجموعات الذكور بالمقارنة بالمجمو عة الضابطة. 